\title{
The queen of the island: On the density and distribution of the Eurasian Collared-Dove (Streptopelia decaocto) in Cozumel
}

\author{
Michelle García-Arroyo ${ }^{1,3}$ (D) - Miguel A. Gómez-Martínez ${ }^{2}$ (D) · lan MacGregor-Fors ${ }^{1,3}$ (D)
}

Accepted: 20 July 2021 / Published online: 11 August 2021

(c) The Author(s) 2021

\begin{abstract}
The Eurasian Collared-Dove (Streptopelia decaocto) is one of the most successful invasive bird species across the world. Worryingly, the invasive dove is a known reservoir of many diseases, some of which can potentially infect mammals (including human beings). Additionally, aggressive behaviors have been recorded toward other bird species resulting in territory and nest usurpation. Thus, the presence of this species poses an important risk for native species with similar habits, particularly in insular systems. Based on this, we carried out this study to assess the density and distribution of the Eurasian Collared-Dove in the island of Cozumel, as well as to evaluate the relationship between their abundance and the environmental characteristics of the places they inhabit. We estimated their distance-corrected densities in the island's largest town and performed an inverse distance weighting (IDW) interpolation to visualize their distribution. We performed a generalized linear model (GLM) to assess relationships between the environmental variables and the abundance of doves using a reduced model procedure. We obtained 137 records of doves present in $94 \%$ of all survey sites and an estimated density of 6.8 ind/ha, for a total of 6,670 doves in San Miguel de Cozumel. We did not find a spatial pattern of the dove's distribution on the urban setting, but we found an interaction between their abundances with tree cover and building height. Our findings, together with previous evidence of infection risk and aggressive behavior, make this species a threat to the native species communities of fragile ecosystems such as the island of Cozumel.
\end{abstract}

Keywords Bird abundance · Insular systems · Invasive species · Island invasions · Urban ecology · Urbanization

\section{Introduction}

The Eurasian Collared-Dove (Streptopelia decaocto) is one of the most successful known invasive bird species with an impressive population growth worldwide (Romagosa and McEneaney 1999). Previous studies have proposed that its genetic plasticity, its high emigration rates, the amelioration

Ian MacGregor-Fors

ian.macgregor@helsinki.fi

1 Red de Ambiente y Sustentabilidad, Instituto de Ecología, A.C. (INECOL), Carretera antigua a Coatepec 351, El Haya, Xalapa 91073 Veracruz, Mexico

2 Instituto de Biotecnología y Ecología Aplicada (INBIOTECA), Universidad Veracruzana, Avenida de las Culturas Veracruzanas 101, Col. Emiliano Zapata, Xalapa 91090 Veracruz, Mexico

3 Faculty of Biological and Environmental Sciences, Ecosystems and Environment Research Programme, University of Helsinki, Niemenkatu 73, 15140 Lahti, Finland of environments and expansion of cultivation, its broad diet, the diversification of their nesting substrates, and its high reproductive output are factors associated with its invasiveness (Romagosa and Labisky 2000; Rocha-Camarero and de Trucios 2002; Bagi et al. 2018). Its origin has been traced to India, where it is distributed among a range of agricultural habitats (Fisher 1953; Stresemann and Nowak 1958). Some studies estimate that the spreading of these doves across Europe started in the 1930s (Kasparek 1996; Rocha-Camarero and de Trucios 2002). Populations that have been closely studied are clear examples of its invasiveness; a study from the United Kingdom illustrates the explosive population growth of an introduced population of $\sim 3,000$ breeding pairs, with a six-fold increase in only nine years ( 19,000 birds) (Hudson 1972). Similarly, significant increases in abundance have also been recorded in invasive populations at rapidly growing Indian cities (Menon and Mohanraj 2016).

The Eurasian Collared-Dove was introduced to the Americas with individuals from Netherlands to Nassau, the capital 
of Bahamas in the 1970s by a pet breeder (Bahamas; Smith 1987). Later, in 1974, 50 individuals escaped from captivity, spreading to other Caribbean islands; evidence of nesting was found the following summer (Smith 1987; Hengeveld 1993; Romagosa and McEneaney 1999). It is believed that the dove spread to the Florida Peninsula and then to the rest of the American continent; however, the details of further invasions were not followed closely (Hengeveld 1993). The worrisome aspects of this dove's invasion into new regions include ecological and the health issues. The Eurasian Collared-Dove has been found to be aggressive toward native species, such as a case of nest usurpation of American Robins (Turdus migratorius) recorded on Texas (Kasner and Pyeatt 2016). This dove is also known to be reservoir of many diseases with potential zoonotic effects toward wildlife, such as the Newcastle disease (Terregino et al. 2003), the West Nile Virus (Panella et al. 2013), and avian chlamydiosis (Chlamydia psittaci; Donati et al. 2015), which can potentially infect mammals (including human beings) (Beckmann et al. 2014).

The Eurasian Collared-Dove is widely distributed in Mexico (González-Zamora et al. 2016). The first record of this species occurred in 2000 in the state of Tamaulipas, located in northeast Mexico (Álvarez-Romero et al. 2008). A year later, an individual was recorded in Baja California, which is located in the westernmost part of the country. Afterwards, in 2002, additional records included the Chihuahua and Coahuila states. Since then, records of the presence and reproduction of the Eurasian Collared-Dove have grown across the country, including the Peninsula of Baja California (Tinajero and Rodriguez-Estrella 2014), Guerrero (Blancas-Calva et al. 2014), Tabasco (Sánchez-Soto 2014), Querétaro (Pineda-López and Malagamba Rubio 2011), and San Luis Potosí (Tinajero and Partida-Pérez 2016). Beyond reports of the doves' presence, reproduction, and competition for feeding resources with other doves that have similar foraging strategies (Poling and Hayslette 2006; e.g., Mourning Dove - Zenaida macroura; Bonter et al. 2010), there are additional alarming reports of this species. For instance, Chablé-Santos et al. (2012) described a highly territorial and aggressive behavior of the Eurasian Collared-Dove during the breeding season, in particular toward the Ruddy Ground Dove (Columbina talpacoti) and the White-winged Dove (Zenaida asiatica) in the Yucatan Peninsula. Additionally, invasive species can potentially reduce the available habitat and resources for native species when their densities increase and spread geographically, as seen in some Indian cities (Menon and Mohanraj 2016). Thus, the presence of this species poses an important risk for native species with similar habits, particularly in insular systems (Clavero et al. 2009).

The island of Cozumel, which the Eurasian Collared-Dove has already invaded, holds many endemic and threatened wildlife species. The island is home to several dove species that could directly compete with the Eurasian Collared-Dove, including the threatened White-crowned Pigeon (Patagioenas leucocephala), as well as the quasi-endemic Caribbean Dove (Leptotila jamaicensis). Given that the invasive dove is concentrated in the main town of the island, antagonistic interactions may still be limited to the urban setting, but there is no certainty if the dove will eventually spread outside of the town, as has happened in disturbed forests and agricultural lands in other Mexican regions (e.g., Chamela, Camacho-Cervantes and Schondube 2018). However, apart from its presence in the island, we know of no available quantitative information on its abundance or distribution. Thus, in this study, we aimed to describe the distribution of the Eurasian Collared-Dove in the principal town of the island (San Miguel de Cozumel) together with a quantitative assessment of their density, and therefore estimates of their urban population. We also assessed the association between the Eurasian Collared-Dove's presence/abundance and vegetation and urban infrastructure variables with the aim of providing information that could be of help in the control and management of the species.

\section{Methods}

\section{Study area}

We conducted this study in the island of Cozumel $\left(20^{\circ}\right.$ $26^{\prime} 09^{\prime \prime} \mathrm{N}, 86^{\circ} 55^{\prime} 20^{\prime \prime} \mathrm{W} ; \sim 1 \mathrm{~m}$ a.s.1.). Cozumel is located northeast of the Yucatan Peninsula (Quintana Roo, Mexico). The island originated in the recent Pleistocene and is considered the largest island in the Mexican Caribbean, with an extent of $489.9 \mathrm{~km}^{2}$ (Flores-Guido 1983). The island concentrates a population of $\sim 86,000$ inhabitants, mostly congregated in San Miguel de Cozumel, which is its population nucleus (INEGI 2017). Apart from the urban area, which covers around $3.23 \%$ of the island, other predominant ecosystems of the island correspond to deciduous and semi-deciduous tropical forest, mangroves, and palm thickets, mainly located in the southeast part of the island (Téllez et al. 1989; Escalante 1996; INEGI 2009).

\section{Bird surveys and environmental variables}

We carried out bird surveys in San Miguel de Cozumel in February of 2020. We selected 35 survey sites distributed across the urban setting considering a criterion of accessibility, avoiding private property and insecure locations (Fig. 1). We conducted one $10 \mathrm{~min}$ point-count (unlimited radius) at each survey site from sunrise and up to four hours later, where all seen and/or heard individuals were recorded (Ralph et al. 1996). We followed a double-observer approach (sensu Nichols et al. 2000) in which the primary observer (IM-F) recorded Eurasian Collared-Doves and a second 
Fig. 1 Map showing the survey sites located in the urban area of San Miguel de Cozumel

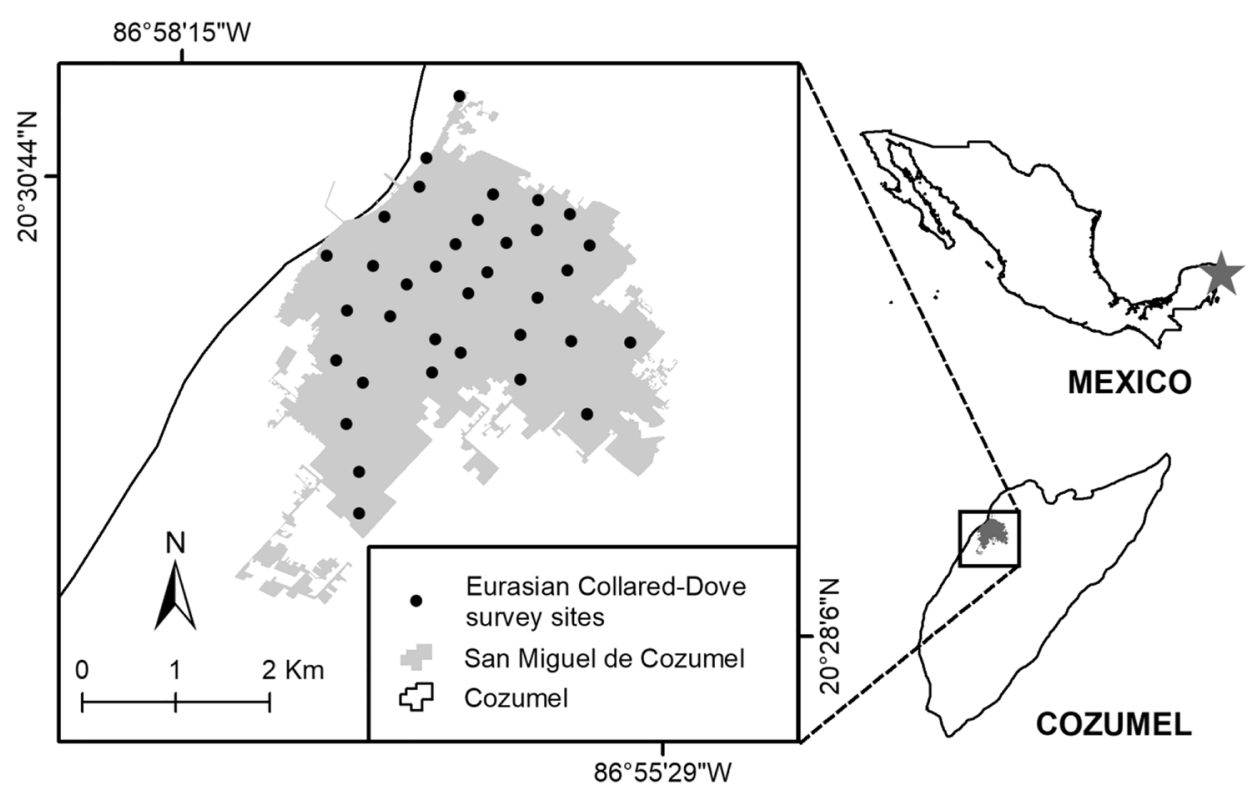

observer (MAG-M) recorded all the distances of each seen individual using a laser rangefinder (Leupold RX-650). We located survey sites at least $280 \mathrm{~m}$ apart from one another to ensure the independence of our observations, with the average distance among nearest sites being $395 \mathrm{~m}( \pm$ SD $114 \mathrm{~m})$.

To assess potential relationships between environmental variables and the abundance of Eurasian Collared-Doves, we described vegetation structure (i.e., tree, shrub, and herbaceous cover; \%), as well as urban infrastructure (i.e., number of cables, maximum building height; $\mathrm{m}$ ), and human activities (i.e., number of passing pedestrians and number of vehicles in $1 \mathrm{~min}$ ).

\section{Data analysis}

We estimated the distance-corrected density of Eurasian Collared-Doves in San Miguel de Cozumel using Distance 6.2 (Thomas et al. 2010). Distance software computes densities (ind/ha) based on the detection probability of individuals from the observer and standardizes detection rates along concentric surveyed areas (Buckland et al. 2001). We also performed an inverse distance weighting (IDW) interpolation to generate a raster (pixel size: $1.32 \mathrm{~m}$ ) that allows for the visualization of the studied dove's distribution within the perimeter of the urban setting. IDW estimates values using the nearest sample points available, which, in turn, are weighted by a power proportional to the inverse of the distance between them and the desired value ( $\mathrm{Li}$ and Heap 2008). Finally, we performed generalized linear models (GLM) to assess potential relationships between the measured variables with presence/abundance of Eurasian Collared-Doves. Considering the nature of our dependent variable data (i.e., counts), we used a Poisson distribution
(Coxe et al. 2009). We followed a reduced model procedure as suggested by Crawley (2013), deleting the variable with the highest P-value until all remaining variables showed significant relationships with the dependent variable. We performed all analyses in R ( $\mathrm{R}$ Core Team 2020).

\section{Results}

We obtained a total of 137 records of Eurasian CollaredDove individuals, which were present in $94 \%$ of all survey sites. The most parsimonious distance-corrected model for the density of doves in San Miguel de Cozumel was of $6.8 \mathrm{ind} / \mathrm{ha}$ ( $84 \% \mathrm{CI}: 5.6-8.2$, effective radius distance: $41 \mathrm{~m})$. Considering that the urban setting covers an area of $987 \mathrm{ha}$, the extrapolation of our results suggests the presence of 5,500-8,100 doves in the urban setting, with an average of $\sim 6,700$ individuals. The depiction of the interpolated data using IDW does not show clear spatial patterns across San Miguel de Cozumel (Fig. 2). This finding could be related to the result of the reduced GLM (overall $r=0.22$ ), which shows that two of the measured variables were significantly related, both negatively, with the presence/abundance of the Eurasian Collared-Dove: (i) tree cover $\left(\chi_{1,33}^{2}=45.5\right.$, $\mathrm{P}=0.03)$, and (ii) maximum building height $\left(\chi_{1,32}^{2}=39.0\right.$, $\mathrm{P}=0.01$ ).

\section{Discussion}

In this study, we report, for the first time, an estimation of the density of the invasive Eurasian Collared-Dove in San Miguel de Cozumel. We also depict the spatial distribution 


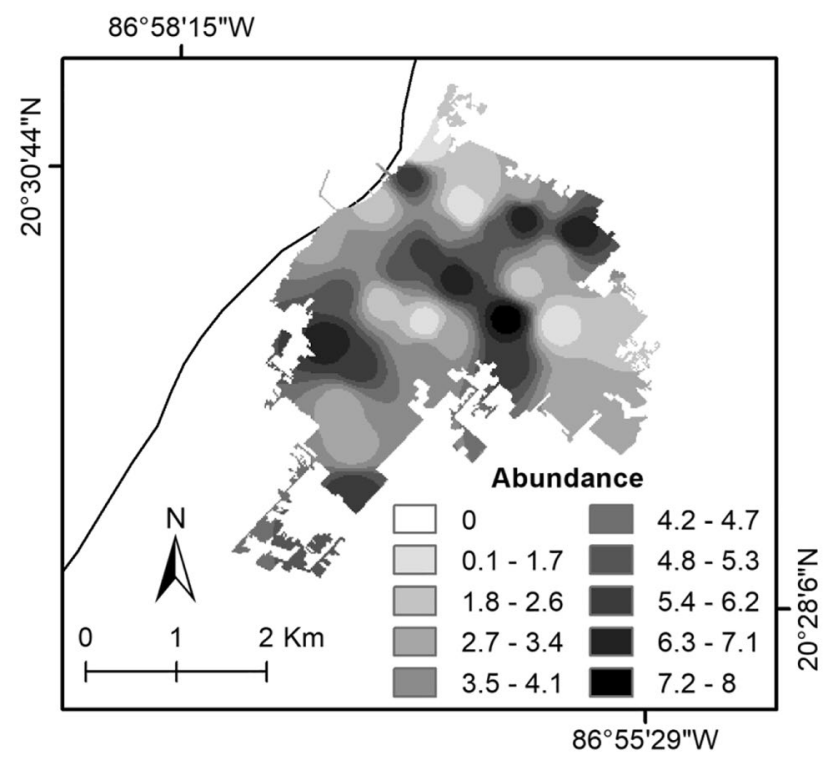

Fig. 2 Map showing the spatial distribution of the Eurasian CollaredDove in San Miguel de Cozumel obtained through interpolating their abundances

of the dove within the limits of the town, as well as its association with vegetation and urban infrastructure variables. Results of this study indicate that there is a substantial number of Eurasian Collared-Doves in San Miguel de Cozumel. Considering the human population reported in the island, there is approximately one invasive Eurasian CollaredDove for every $\sim 13$ inhabitants. It is important to note that this study was performed in the last phase of winter, so we assume that our count excludes, or at least has a minimum number of, fledgling, immature, and juvenile individuals. Yet, the breeding season of the species has been known to be prolonged (mainly March-October), with year-round breeding in some regions close to their native distribution (Baptista et al. 2020). Previous studies have shown that this dove can have explosive population increases as well as impressive spread of their invasive populations (Hudson 1972; Cecil 2004), which is likely to occur in the island if no management actions are implemented.

The interpolation of our presence/abundance data for Eurasian Collared-Doves in San Miguel de Cozumel showed no apparent spatial pattern, which could be due to the site-specific traits related to its numbers. Results from the GLM are clear in that only two of the measured variables were negatively and significantly related to the presence/abundance of these doves: tree cover and maximum building height. Thus, more doves were recorded in sites with less tree cover and also sites with smaller buildings. Sites where we recorded $\geq 5$ Eurasian Collared-Doves correspond to locations where the highest building was twostories high (average $6.2 \mathrm{~m} \pm \mathrm{SD} 1.4 \mathrm{~m}$ ) and had an average of $22 \%$ tree cover $( \pm$ SD $16 \%)$. Previous studies have reported that Eurasian Collared-Doves positively associate with built-up areas (Bermúdez-Cavero et al. 2021; Saâd et al. 2021); these doves are considered an 'urban dweller' in Algeria in contrast with other dove species of the same genus (Saâd et al. 2021). However, the Eurasian CollaredDove has seasonal patterns in relation to buildings. For instance, Havlíček et al. (2021) report that the species is positively associated with buildings during the breeding season but avoid them during winter. This may be due to this species frequently using these structures as nest sites during the breeding season. Associations with other types of variables have also been reported. For instance, warm areas have been shown to be favorable for their presence, and proximity to the coast were positively related to their abundances (Fujisaki et al. 2010), which is why it is not surprising to find that the dove is doing so well in the tropical and coastal San Miguel de Cozumel.

Results of this study provide evidence of the density, distribution, and local environmental variables related with the Eurasian Collared-Dove in San Miguel de Cozumel. Our results suggest that the population of this invasive dove is well established in the urban setting of the island. Given that previous studies from the USA have shown that this dove is present in non-urban settings, including forests, shrublands, grasslands, and croplands (e.g., Fujisaki et al. 2010), there is evidence that suggests that it can spread to other systems in the island, with a higher probability to colonize shrublands than forested systems (Scheidt and Hurlbert 2014), such as the palm thickets located along the eastern coast of Cozumel. Actually, we also recorded a few Eurasian CollaredDove individuals in electricity/telephone cables along the road system of the island (pers. obs.), which is worrisome in light of potential invasions into non-urban systems. This process may take time, given that the dove recently colonized and would need to go through a lag-phase (Sakai et al. 2001; Crooks 2005; Aagaard and Lockwood 2014). Thus, given the ecological and health risks that this dove poses, we strongly encourage the local authorities to swiftly and firmly begin with the control and management of this species, together with close monitoring across the island.

Acknowledgements We greatly thank Eleanor Diamant for her invaluable proof read and English grammar check. MG-A acknowledges the scholarship and financial support provided by the National Council of Science and Technology (CONACYT 700755) and the Doctoral Program of the Instituto de Ecología, A.C. (INECOL). MAG-M acknowledges the scholarship and financial support provided by the National Council of Science and Technology (CONACYT 703624), and the Ph.D. Program of the Instituto de Biotecnología y Ecología Aplicada (INBIOTECA) of the Universidad Veracruzana.

Authors' contributions IM-F conceived the idea; IM-F and MAG-M collected data; MG-A and IM-F analyzed the data; MG-A, MAG-M and IM-F wrote the paper. 
Funding (information that explains whether and by whom the research was supported) Open access funding provided by University of Helsinki including Helsinki University Central Hospital. This project was funded by the Mexican Center for Innovation in Ocean Energy (CEMIE-Océano; 80045).

Open Access This article is licensed under a Creative Commons Attribution 4.0 International License, which permits use, sharing, adaptation, distribution and reproduction in any medium or format, as long as you give appropriate credit to the original author(s) and the source, provide a link to the Creative Commons licence, and indicate if changes were made. The images or other third party material in this article are included in the article's Creative Commons licence, unless indicated otherwise in a credit line to the material. If material is not included in the article's Creative Commons licence and your intended use is not permitted by statutory regulation or exceeds the permitted use, you will need to obtain permission directly from the copyright holder. To view a copy of this licence, visit http://creativecommons.org/licenses/by/4.0/.

\section{References}

Aagaard K, Lockwood J (2014) Exotic birds show lags in population growth. Divers Distrib 20:547-554

Álvarez-Romero J, Medellín RA, Oliveras de Ita A et al (2008) Animales exóticos en México: Una amenaza para la biodiversidad. Comisión Nacional Para el Conocimiento y Uso de la Biodiversidad, México

Bagi Z, Dimopoulos EA, Loukovitis D et al (2018) MtDNA genetic diversity and structure of Eurasian Collared Dove (Streptopelia decaocto). PLoS One 13:e0193935

Baptista LF, Trail PW, Horblit HM, Boesman P, Garcia EFJ, Kirwan GM (2020) Eurasian Collared-dove (Streptopelia decaocto). In: del Hoyo J, Elliott A, Sargatal J, Christie DA, de Juana E (eds). Handbook of the Birds of the World Alive Lynx Edicions, Barcelona. https://www.hbw.com/node/54154. Accessed 24 Feb 2020

Beckmann KM, Borel N, Pocknell AM et al (2014) Chlamydiosis in British Garden Birds (2005-2011): Retrospective diagnosis and Chlamydia psittaci genotype determination. EcoHealth 11:544-563

Bermúdez-Cavero AO, Bernat-Ponce E, Gil-Delgado JA, Lópezlborra GM (2021) Urban landscape selection by Eurasian collared dove (Streptopelia decaocto) in eastern Spain. Caldasia. https://doi.org/10.15446/caldasia.v43n1.82214

Blancas-Calva E, Castro-Torreblanca M, Blancas-Hernández JC (2014) Presencia de las palomas turca (Streptopelia decaocto) y africana de collar (Streptopelia roseogrisea) en el estado de Guerrero, México. Huitzil 15:10-16

Bonter DN, Zuckerberg B, Dickinson JL (2010) Invasive birds in a novel landscape: habitat associations and effects on established species. Ecography 33:494-502

Buckland ST, Anderson D, Burnham K et al (2001) Introduction to distance sampling: estimating abundance of biological populations. Oxford University Press, New York

Camacho-Cervantes M, Schondube JE (2018) Habitat use by the invasive exotic Eurasian Collared-Dove (Streptopelia decaocto) and native dove species in the Chamela-Cuixmala region of West Mexico. Wilson J Ornithol 130:902-907

Cecil RI (2004) Range expansion of the Eurasian Collared-Dove in Iowa. Iowa Bird Life 74:70-73

Chablé-Santos J, Gómez-Uc E, Hernández-Betancourt S (2012) Registros reproductivos de la paloma de collar (Streptopelia decaocto) en Yucatán, México. Huitzil 13:1-5

Clavero M, Brotons L, Pons P, Sol D (2009) Prominent role of invasive species in avian biodiversity loss. Biol Conserv 142:2043-2049
Coxe S, West SG, Aiken LS (2009) The analysis of count data: A gentle introduction to Poisson Regression and its alternatives. J Pers Assess 91:121-136

Crawley MJ (2013) The R book, 2nd edn. Wiley, Chichester, West Sussex, United Kingdom

Crooks JA (2005) Lag times and exotic species: The ecology and management of biological invasions in slow-motion. Écoscience 12:316-329

Donati M, Laroucau K, Delogu M et al (2015) Chlamydia psittaci in Eurasian Collared Doves (Streptopelia decaocto) in Italy. J Wildlife Dis 51:214-217

Escalante P (1996) Tipos de vegetación de la Isla de Cozumel, Quintana Roo. Extracted from project B010 Avifauna de la Isla de Cozumel. Instituto de Biología. Universidad Nacional Autónoma de México (UNAM), funded by Comisión Nacional para el Conocimiento y Uso de la Biodiversidad (CONABIO)

Fisher J (1953) The Collared Turtle Dove in Europe. Brit Birds 46:153-182

Flores-Guido JS (1983) Vegetación insular de la Península de Yucatán. Bot Sci 45:23-37

Fujisaki I, Pearlstine EV, Mazzotti FJ (2010) The rapid spread of invasive Eurasian Collared Doves Streptopelia decaocto in the continental USA follows human-altered habitats. Ibis 152:622-632

González-Zamora DA, Angulo-Castellanos LF, Hernández-Vázquez S et al (2016) Presencia de la paloma turca (Streptopelia decaocto) en el archipiélago de Revillagigedo, México. Huitzil 17:151-154

Havlíček J, Riegert J, Bandhauerová J et al (2021) Species-specific breeding habitat association of declining farmland birds within urban environments: conservation implications. Urban Ecosyst. https://doi.org/10.1007/s11252-021-01111-9

Hengeveld R (1993) What to Do about the North American Invasion by the Collared Dove? J Field Ornithol 64:477-489

Hudson R (1972) Collared Doves in Britain and Ireland during 196570. Brit Birds 58:105-139

INEGI (2017) Anurario estadístico y geográfico de Quintana Roo 2017. Instituto Nacional de Estadística y Geografía (INEGI), Quintana Roo, México

INEGI (2009) Prontuario de Información Geográfica Municipal de los Estados Unidos Mexicanos: Cozumel, Quintana Roo. Instituto Nacional de Estadística y Geografía (INEGI), Mexico

Kasner AC, Pyeatt DN (2016) Eurasian Collared-Dove (Streptopelia decaocto) Usurps Nest of American Robins (Turdus migratorius). Wilson J Ornithol 128:198-200

Kasparek M (1996) Dispersal and range extension of the Collared Dove (Streptopelia decaocto) in Europe. J Ornithol 137:1-34

Li J, Heap AD (2008) A review of spatial interpolation methods for environmental scientists. Geoscience Australia, Record 2008(23): 137

Menon M, Mohanraj R (2016) Temporal and spatial assemblages of invasive birds occupying the urban landscape and its gradient in a southern city of India. J Asia-Pac Biodivers 9:74-84

Nichols JD, Hines JE, Sauer JR et al (2000) A double-observer approach for estimating detection probability and abundance from point counts. Auk 117:393-408

Panella NA, Young G, Komar N (2013) Experimental infection of Eurasian collared-dove (Streptopelia decaocto) with West Nile virus. J Vector Ecol 38:210-214

Pineda-López R, Malagamba Rubio A (2011) Nuevos registros de aves exóticas en la ciudad de Querétaro, México. Huitzil 12:22-27

Poling TD, Hayslette SE (2006) Dietary overlap and foraging competition between mourning doves and eurasian collared-doves. J Wildlife Manage 70:998-1004

R Core Team (2020) R: A language and environment for statistical computing. R Foundation for Statistical Computing, Vienna, Austria 
Ralph CJ, Geupel GR, Pyle P et al (1996) Handbook of field methods for monitoring landbirds. U.S.D.A., Forest Service, Pacific Southwest Research Station. Gen. Tech. Rep. PSW-GTR-144, Albany

Rocha-Camarero G, de Trucios SJH (2002) The spread of the Collared Dove Streptopelia decaocto in Europe: colonization patterns in the west of the Iberian Peninsula. Bird Study 49:11-16

Romagosa C, McEneaney T (1999) Eurasian collared-dove in North America and the Caribbean. North American Birds 53:348-353

Romagosa CM, Labisky RF (2000) Establishment and dispersal of the Eurasian Collared-Dove in Florida. J Field Ornithol 71:159-166

Saâd N, Hanane S, El Hak Khemis MD, Farhi K (2021) Landscape composition governs the abundance patterns of native and invasive Columbidae species along an urban-rural gradient and contribute to their partitioning. Biol Inv 23:2077-2091

Sakai AK, Allendorf FW, Holt JS et al (2001) The population biology of invasive species. Annu Rev Ecol Syst 32:305-332

Sánchez-Soto S (2014) Presencia de la paloma de collar (Streptopelia decaocto) en Tabasco, México. Zeledonia 18:97-100

Scheidt SN, Hurlbert AH (2014) Range expansion and population dynamics of an invasive species: The eurasian collared-dove (Streptopelia decaocto). PLoS One 9:e111510
Smith PW (1987) The Eurasian collared-dove arrives in the Americas. American Birds 41:1370-1379

Stresemann E, Nowak E (1958) Die Ausbreitung der Türkentaube in Asien und Europa. J Ornithol 99:243-296

Téllez O, Cabrera E, Linares E, Bye R (1989) Las Plantas de Cozumel (Guía Botánico-Turística de la Isla de Cozumel, Quintana Roo). Instituto de Biología UNAM, Mexico

Terregino C, Cattoli G, Grossele B et al (2003) Characterization of Newcastle disease virus isolates obtained from Eurasian collared doves (Streptopelia decaocto) in Italy. Avian Pathol 32:63-68

Thomas L, Buckland ST, Rexstad EA et al (2010) Distance software: design and analysis of distance sampling surveys for estimating population size. J Appl Ecol 47:5-14

Tinajero R, Partida-Pérez A (2016) La tórtola turca (Streptopelia decaocto) en San Luis Potosí, México, con notas sobre su reproducción. Huitzil 17:145-150

Tinajero R, Rodriguez-Estrella R (2014) Increasing distribution and first nesting record of the Eurasian Collared-Dove (Streptopelia decaocto) in Baja California Peninsula, Mexico. Rev Mex Biodivers 85:898-909 